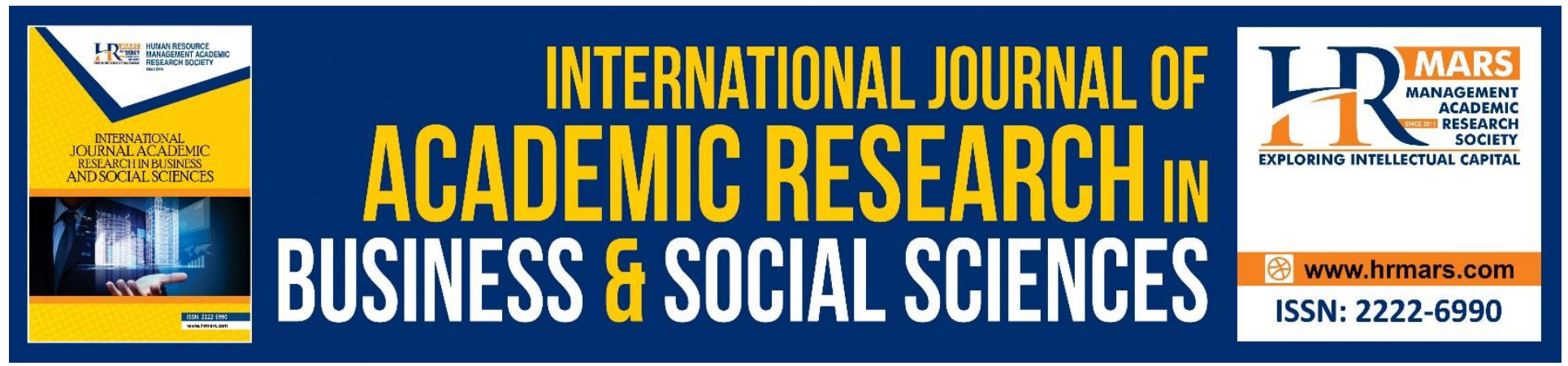

\title{
Exploring the Predominant Qualities of Head Teachers towards Achieving School Success
}

Norlizaiha Md Noor, Wan Norhayate Wan Daud, Norfadzilah Rashid, Asyraf Afthanorhan

To Link this Article: http://dx.doi.org/10.6007/IJARBSS/v8-i11/5173

DOI: $10.6007 /$ IJARBSS/v8-i11/5173

Received: 26 Oct 2018, Revised: 29 Nov 2018, Accepted: 30 Nov 2018

Published Online: 02 Dec 2018

In-Text Citation: (Noor, Daud, Rashid, \& Afthanorhan, 2018)

To Cite this Article: Noor, N. M., Daud, W. N. W., Rashid, N., \& Afthanorhan, A. (2018). Exploring the Predominant Qualities of Head Teachers towards Achieving School Success. International Journal of Academic Research in Business and Social Sciences, 8(11), 1324-1330.

Copyright: (C) 2018 The Author(s)

Published by Human Resource Management Academic Research Society (www.hrmars.com)

This article is published under the Creative Commons Attribution (CC BY 4.0) license. Anyone may reproduce, distribute, translate and create derivative works of this article (for both commercial and non-commercial purposes), subject to full attribution to the original publication and authors. The full terms of this license may be seen

at: http://creativecommons.org/licences/by/4.0/legalcode

Vol. 8, No. 11, 2018, Pg. 1324 - 1330

http://hrmars.com/index.php/pages/detail/IJARBSS

JOURNAL HOMEPAGE

Full Terms \& Conditions of access and use can be found at http://hrmars.com/index.php/pages/detail/publication-ethics 


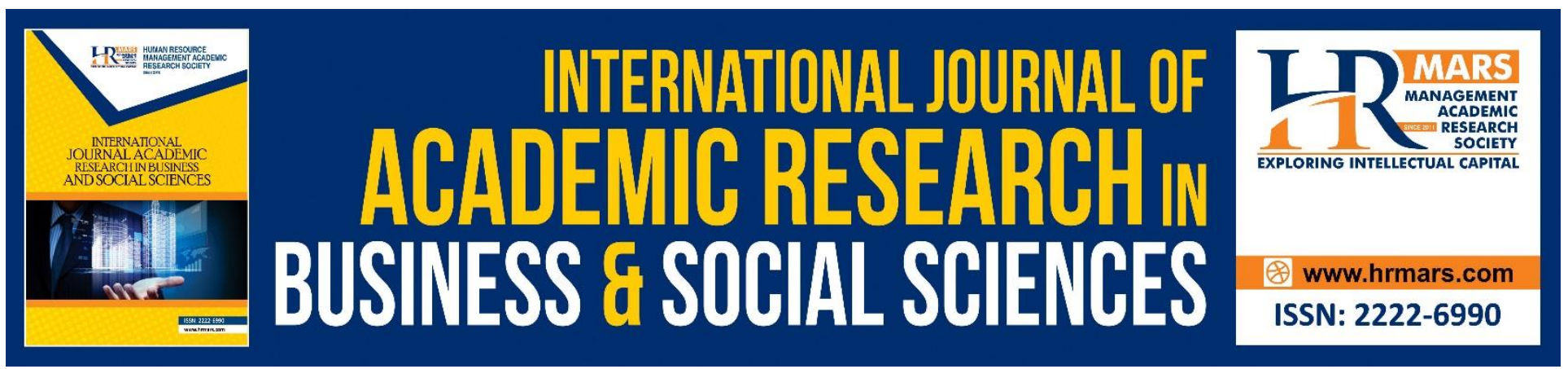

\title{
Exploring the Predominant Qualities of Head Teachers towards Achieving School Success
}

\section{Norlizaiha Md Noor, Wan Norhayate Wan Daud, Norfadzilah Rashid, Asyraf Afthanorhan}

Faculty of Economics and Management Sciences, Universiti Sultan Zainal Abidin (UniSZA)

Gong Badak Campus 21300 Kuala Terengganu, Terengganu, Malaysia

Corresponding Author: norlizaiha143@yahoo.com.my

\begin{abstract}
This paper aims to explore the predominant qualities of head teachers towards achieving school success. The objectives of this paper are, firstly, to determine the qualities of the primary head teachers towards the school success, secondly, to analyse the effect of qualities of the head teachers on school performance and thirdly, to develop a framework to enhance the head teachers' qualities in achieving school success. As to achieve the research objectives, this qualitative study gives a focus on multiple case studies. Three expected significant outcomes will be revealed, firstly, the qualities possessed by the head teachers, secondly, the effect of predominant qualities possessed by the head teachers and thirdly, the framework how to enhance the head teachers qualities in achieving school success. The findings of this study hopefully will provide a significant contribution to the school administrators in managing their schools in wise, outstanding and creative ways without neglecting the roles of teachers and students to achieve school success.
\end{abstract}

Keywords: Head Teachers Predominant Qualities, School Success, Head Teacher's Leadership

\section{INTRODUCTION}

In respect to the 21st century education revolution, there have been some transformations occur in the teacher's role, head teacher's responsibilities and the overall expectations on students. It is undeniable that the quality of head teachers as the school leaders has been constantly recognised as one of the most essential school-based factors in students' achievement. A head teacher needs a cooperative attempt from his subordinates and broadly distributed leadership to fulfil the challenges in achieving success.

Many countries around the world nowadays put a serious consideration on the sustainability in education, for instance, Finland. Finland core curriculum consists of curriculum frameworks, the recognition of the core subjects, and a rich definition of how much time each topic should be allocated. Finnish classrooms highlight the significance of learning through doing, and put specific 
emphasis on working in group, creativity and problem-solving skills. There is no external standardised test and the smoothness of education relies on the proficiency and liability of committed teachers. In fact, principals also do some teaching and some reach to 20 lessons per week.

Japan also has a very consistent curriculum, and carefully centred on central topics, with a strong goal of nurturing deep conceptual understanding. Academic programmes are based on a logical sequence and applied at a very high level of cognitive challenge. Learning the main subject matter falls under the main priority in education in Japan (Eid, 2014). Principals are regarded to be fully knowledgeable in the organisation vision area because of their acquaintance of the tasks, the materials to be learned, and their strategies for learning.

While in South East Asia, Singapore is the exact example. Singaporean students are provided with a steady basis in the core literacy areas, numeracy and scientific literacy. Teachers are given more room to make learning more occupied and efficient while students have ample time to discover their interested learning area. Besides, the high quality leadership practice also contributes to the success of Singaporean education. Based on a study by Wang, Gurr and Drysdale (2016), revealed that personal qualities, beliefs and values of the school principals contribute to the good school performance in Singapore.

Regarding Malaysia, education also becomes as a continuing attempt towards further developing the individuals' potential in a holistic and united manner. Ministry of Education (2012) in a Preliminary Report Malaysia Education Blueprint 2013-2025 (MEB) 2011 states that the Malaysian education system aspires to ensure that every student in every school in every state achieves their full potential. In line with the government policy to equip students with 21st century skills, a new curriculum has been designed, namely KSSR (primary level) and KSSM (secondary level). It aims to increase and adopt the use of science and technology, develop values, and understand humanitarian issues. Students are taught to be active decision makers and accountable for their actions using the application of higher-order thinking skills (HOTS). There is no more exam-oriented system and students are encouraged to work together rather being competing to be the best. The Ministry has also introduced an induction programme for the school leaders to equip them with the skills needed for their critical first three years of leadership.

School organisation as the core of national education is dependent on the leadership management and members of the organisation to achieve progress (Abdul Wahab, Mohd Fuad, Ismail \& Majid, 2014). Head teachers, who form the core of a school's leadership team, are regarded as important determinants of students' excellence and school success. Therefore, a school's academic success is very dependent on school leader (Abdul Wahab et al., 2014). International research on school leadership shows that an outstanding principal; one who focuses on instructional and not administrative leadership can raise student outcomes by as much as $20 \%$. As the leading professional in the school, the head teacher should ensure the school is well managed and organised, providing leadership and direction (Kirui \& Osman, 2012).

Johnson (2011) claimed that in the past, a principal or school administrator worked in isolation and was predominantly concerned with personal autonomy and the top down approach. Nowadays, with the integration of spirituality, school organisation has shifted to the more appropriate term of "learning leader". A good management style with a qualitative measure of staff empowerment and motivation will give the teachers feeling of motivated in their work. Wang et al. (2016) from their 
INTERNATIONAL JOURNAL OF ACADEMIC RESEARCH IN BUSINESS AND SOCIAL SCIENCES

Vol. 8, No. 11, Nov, 2018, E-ISSN: 2222-6990 @ 2018 HRMARS

study have found out that being open to feedback from others was the most prominent quality of the school success.

In this regard, the main objective of this research paper is to determine the qualities of the primary head teachers towards the school success. The $21^{\text {st }}$ century education demands the school organisation to be managed in wise, outstanding and creative ways without neglecting the roles of teachers and students to achieve school success.

\section{LITERATURE REVIEW}

Chan and Kaur (2013) indicated that from a range of researches done in different countries, they manifest that leadership plays a key role in the development of school and any type of alteration that has been done for the school development. A highly successful head teacher is not known for the job per se, but more significantly to the chance to create something different in schools. Thus, working environment is pivotal since it moulds the attitude of teachers towards work and the head teachers need to always maintain good mechanism to ensure the stable environment for teaching and learning activities (Christopher, 2014).

Head teachers need to know how to encourage efficient performance of their teachers and this can be achieved by identifying and trying to satisfy their subordinates (Adeyemi, 2011). Omar (2016) claimed that for the schools to succeed it depends on the elements such as knowledge, skills, quality, and commitment of the head teachers. The head teachers are committed to the school goals when they practice collaborative and cooperative work with the subordinates to find solutions to encourage school and teaching profession.

Based on Butcher's (2014) study, she found out that committed head teachers would express their determination to do whatever they could in order to enable their schools to achieve success. How the head teachers organise the schools is the core point that leads the school forward or otherwise (Ministry of Education Malaysia, 2014; Ibrahim \& Wahab, 2012). Besides, effective head teachers also need to gain teaching experience in a classroom environment first to relate to the professionals they are directly in charge of supervising.

Amin, Shah and Tatlah (2013) stated that any head teachers who practice the transformational leadership are capable in motivating their teachers to let them change their values and attitude by being dedicated towards the mission and vision of our education. This is in line with the finding from a study done by Abdul Wahab et. al, (2014) where they found out that transformational leadership practiced by the head teachers in their study is one of the elements that contributes to the followers' job satisfaction. Further, Abdulghani (2016) also stated in his study on exploring the factors which promote teachers' job satisfaction; that the transformational leadership style showed by the head teachers in the studied schools strongly affected teachers' job satisfaction. Ahmad Tatlah and Iqbal's study (2012) also revealed that there was a significant relationship between the head teachers' leadership style and the school effectiveness.

\section{PROBLEM STATEMENT}

Malaysian education faces some challenges in the term of policies, teachers, and students to fulfil the aspiration of the nation. The introduction of a new policy which is KSSR for primary school has affected both the teachers and students. School-Based Assessment (SBA) in public schools has been 
introduced in KSSR policy to substitute the present public examinations. However, it contributes to the additional work need to be carried out by the teachers. According to Samsudin, Rengasamy, Mat Jizat, Ab Wahid and Abdul Jalil (2014), teachers' workload has increased since the announcement of SBA because teachers must conduct the assessment process from the beginning. Maarof and Munusamy (2015) revealed that some teachers perceive that the KSSR policy is implemented after a short notice therefore the teachers have limited time to prepare themselves. While Sekharan Nair et al. (2014), through their study also revealed that the teachers perceived that this new policy demands a lot of their time, energy and commitment. In KSSR, students need to apply higher-order thinking skills (HOTS) that are complex thinking to preserve information and apply problem-solving solutions to the real-world problems. However, for weaker students, it can be a problem because it needs them to be fully committed to the class discussion, having the ability to debate and solving problems.

Teachers also contribute to some of the problems arise in schools. Some teachers are not aware with the hands-on activities and fail to create a learning environment that fulfils students' multiple intelligence. A study by Omar, Jain and Noordin (2013) confirmed that the teachers need to have active learning sessions to let the students feel engaged and more motivated. Other than that, many teachers view new curriculum programmes signify new teaching competencies to be developed which demand them to attend extra courses and workshops. Workload facing by the teachers nowadays is also one of the factors for the unmotivated and uncommitted teachers. Regarding the education transformation, nowadays, teachers are overstrained with clerical tasks and this has disheartened them. Besides teaching, they also need to supervise students in and out of class and show appropriate personal contact while carrying out other school duties. Exhausted, frazzled and demoralised teachers because of the heavy workload will result in ineffective and uncreative actions in the classroom.

Students also contributes to the problems in schools. Sometimes their attitudes towards certain subjects, for instance, English Language may cause to a problem to the school achievement. Lack of interest prevents a student of any motivation to study. Teachers who repeatedly teach the same thing for a long time and use the same methods every day will also contribute to losing interest among students. Some students lose motivation when they encounter challenges because they believe that learning is generally fast and easy. There are also students who do have clear goals as to where they are heading. This is supported by TRAN's (2013) study where it is found out that the student respondents did not have clear ideas about their future. If they have ones, they still thought that it was quite difficult for them to achieve their dreams because sometimes the environment hinders then to achieve their dreams.

\section{CONCLUSION}

This study investigates the relationship between the predominants qualities possessed by head teachers in leadership and school success. The findings of this study hopefully will provide a significant information to the MoE, head teachers, and schools concerning the factors needed by the head teachers to achieve school success. 
INTERNATIONAL JOURNAL OF ACADEMIC RESEARCH IN BUSINESS AND SOCIAL SCIENCES

Vol. 8, No. 11, Nov, 2018, E-ISSN: 2222-6990 @ 2018 HRMARS

\section{REFERENCES}

Abdulghani, N. K. (2016). A CORRELATIONAL STUDY OF PRINCIPALS'

LEADERSHIP STYLES ON TEACHERS' JOB SATISFACTION IN GIRLS' PRIVATE ELEMENTARY

SCHOOLS IN SAUDI ARABIA (Unpublished doctoral's thesis): The Pennsylvania State University.

Abdul Wahab, J., Mohd Fuad, C., Ismail, H., \& Majid, S. (2014). Headmasters'

Transformational Leadership and Their Relationship with Teachers' Job Satisfaction and Teachers' Commitments. International Education Studies, Vol. 7(No.13).

Adeyemi, O. T. (2011). Principals' Leadership Styles and Teachers' Job Performance in Senior Secondary Schools in Ondo State, Nigeria. Current Research Journal of Economic Theory , 3, 3rd ser.

Ahmad Tatlah, I., \& Iqbal, M. (2012). Leadership Styles and School Effectiveness:

Empirical Evidence from Secondary Level. Procedia - Social and Behavioral Sciences, 69, 2012th ser.

Butcher, A. C. (2014). The Relationship Between Principal Leadership and Improving Achieving Status in Secondary Schools: A Multiple Site Case Study (Unpublished doctoral's thesis): University of Arkansas

Chan, D. R. \& Kaur, P. S. (2013). Principal leadership for outstanding educational outcomes. Journal of Educational Administration, 43(4), 33

Christopher, N. (2014). FACTORS INFLUENCING SECONDARY SCHOOL TEACHERS' JOB SATISFACTION LEVELS IN LANG'ATA DISTRICT, NAIROBI- KENYA DEPARTIMENT OF EDUCATION: UNIVERSITY OF ELDORET . International Journal of Community and Cooperative Studies , 1(2).

Eid, F. H. (2014). Higher education and the quality of teaching: Inquiry in a Japanese academic context . Research in Higher Education Journal , 24.

Ibrahim, M. S., \& Wahab, J. A. (2012). Educational leadership. Bangi: Universiti Kebangsaan Malaysia

Johnson, S. C. (2011). School Administrators and the Importance of Utilizing Action Research. International Journal of Humanities and Social Science, 1(14).

Kirui, K., \& Osman, A. (2012). Headteachers' Perception of Their Roles in Secondary Schools in Kenya: A Study of Kericho Day Secondary School in Kericho County. International Journal of Humanities and Social Science , 2(23). 
INTERNATIONAL JOURNAL OF ACADEMIC RESEARCH IN BUSINESS AND SOCIAL SCIENCES

Vol. 8, No. 11, Nov, 2018, E-ISSN: 2222-6990 (C) 2018 HRMARS

Maarof, N., \& Munusamy, I. M. (2015). Teacher's Belief of the new Standard Curriculum for Primary Schools (KSSR) in Teaching English as (ESL) in Malaysian Schools: A Qualitative approach. Asian Journal of Multidisciplinary Studies , 3(5)

Ministry of Education. (2012). Preliminary Report: Malaysia Education Blueprint 20132025. Putrajaya Malaysia: Author

Ministry of Education Malaysia. (2014). Pelan Pembanguan Pendidikan Malaysia 20132025. Putrajaya: KPM

Omar, A. M. (2016). Effect of Leadership Style on School Performance of the Secondary Schools in Wadajir District, Mogadishu, Somalia. Journal of Applied Management Science , 2(5).

Omar, S., Jain, J., \& Noordin, F. (2013). Motivation in Learning and Happiness among the Low Science Achievers of a Polytechnic Institution: An Exploratory Study. 6th International Conference on University Learning and Teaching (InCULT 2012) (Vol. 90, pp. 702-711).

Samsudin, N., Rengasamy, P., Mat Jizat, J. E., Ab Wahid, H., \& Abdul Jalil, N. (2014). INVESTIGATING TEACHERS' READINESS, UNDERSTANDING AND WORKLOAD IN IMPLEMENTING SCHOOL BASED ASSESSMENT (SBA) (pp. 25-31). 11th International Conference on Cognition and Exploratory Learning in Digital Age (CELDA 2014) .

Sekharan Nair, G. K., Setia, R., Abdul Samad, N., Raja Zahri, R., Luqman, A., Vadeveloo, T., \& Che Ngah, H. (2014). Teachers' Knowledge and Issues in the Implementation of SchoolBased Assessment: A Case of Schools in Terengganu. Asian Social Science, 10(3).

Tran, N. T. (2013). Factors associated with low educational motivation among ethnic minority students in Vietnam. Ritsumeikan Journal of Asia Pacific Studies, 32, 124-136.

Wang, L. H., Gurr, D., \& Drysdale, L. (2016). Successful school leadership: Case Studies of four Singapore primary schools. Journal of Educational Administration , 54(3). 